\title{
Briefing: Embedding transdisciplinarity in engineering approaches to infrastructure and cities
}

Joanne M. Leach BSc, MSc, PhD

UKCRIC Research Fellow, Department of Civil Engineering, University of Birmingham, Birmingham, UK (Orcid:0000-0001-7526-624X)

(corresponding author: j.leach@bham.ac.uk)
Chris D. F. Rogers Eur Ing, BSc, PhD, CEng, MICE, FCIHT, SFHEA UKCRIC Director of Research Integration and Professor of Geotechnical Engineering, Department of Civil Engineering, University of Birmingham, Birmingham, UK (Orcid:0000-0002-1693-1999)

Many of the specialisms on which infrastructure and cities rely for their effective design, construction, operation, governance, management and maintenance are underpinned by the principles of certainty, accuracy, precision and prediction. Not least of these is civil engineering. Yet infrastructures and cities are characterised by complexity and emergence. In recent decades, understandings of infrastructures and cities have begun to reflect these properties, and in particular, transdisciplinarity is promoted as critical to advancing these new understandings. However, this presents conceptual and operational challenges for civil engineering, as there is a fundamental mismatch between the certainty, accuracy and precision required by engineers and the complexity and emergence of transdisciplinary research approaches. The forms of value arising from these research approaches are themselves contentious, leaving engineers exposed to competing claims and making them ill prepared to exploit new insights to full advantage. This briefing explores these mismatches and contentions and proposes a set of four principles that underpin successful transdisciplinary research, laying the foundation for transforming research in infrastructure and cities by leveraging emergent, transdisciplinary approaches.

\section{Introduction}

Paul Jowitt (2004), a past president of the Institution of Civil Engineers, reflected that since its inception, civil engineering has been largely concerned with technical rationality: narrow technical approaches to problem solving that have not taken into account wider social and environmental impacts. 'No one foresaw that Henry Ford's production line of black Model Ts would lead inexorably to changes in urban form, large-scale urban congestion, air pollution (and its linkage to the higher incidence on [sic] child asthma), $\mathrm{CO}_{2}$ emissions or global warming and climate change' (Jowitt, 2004: p. 82). Now, however, engineers are increasingly asked to grapple with wicked problems such as sustainability, resilience, liveability, urbanisation, climate change and smartness (noting that smartness is truly smart only if it delivers on all of these allied agendas (Cavada et al., 2017)). Wicked problems those problems that are intractable and often unsolvable (Rittel and Webber, 1973) - require system-level solutions and the twenty-first century marks the point at which civil engineering started to move away from short-term 'technical rationality' and towards a futurelooking 'systems/holistic viewpoint' (Jowitt, 2004). This change in mindset, however, is no small task, and it propels engineers into non-engineering domains, including those of complexity science, big data and the Internet of things.

Head and Xiang (2016) argue that wicked problems favour adaptive, participatory and transdisciplinary approaches. There is no agreed definition of transdisciplinarity, but one of the most comprehensive definitions is that provided by Jahn et al. (2012: pp. 8-9): 'a critical and self-reflexive research approach that relates societal with scientific problems; it produces new knowledge by integrating different scientific and extra-scientific insights; its aim is to contribute to both societal and scientific progress; integration is the cognitive operation of establishing a novel, hitherto non-existent connection between the distinct epistemic, social-organizational and communicative entities that make up the given problem context'.

Three characteristics of transdisciplinarity distinguish it from the closely related concepts of interdisciplinarity and multidisciplinarity. First, transdisciplinarity addresses societal problems. Second, it engages beyond science and academia. Third, it creates transformation through synthesis. Transdisciplinarity is, therefore, essential if civil engineers are to respond effectively to societal challenges and to shape future research agendas.

This study seeks to answer two questions: (a) how are transdisciplinary approaches suited to the engineering of infrastructure and cities and $(b)$ how is the engineering of infrastructure and cities suited to transdisciplinary approaches? It was undertaken for UKCRIC - the UK Collaboratorium for Research on Infrastructure and Cities (see UKCRIC, 2020a). Through its four missions (see UKCRIC, 2020b), UKCRIC is supporting the renewal, sustainment and improvement of infrastructure and cities in the UK and elsewhere by creating a paradigm shift in how and by whom infrastructure and cities research is conducted (for UKCRIC's research capability in cities, see UKCRIC Coordination Node (2019)). The authors conducted a review of the literature on transdisciplinarity (and its closely related terms and concepts) alongside a review of the evolution of civil engineering approaches to infrastructure and cities. The 
outcome is a set of principles for enabling transdisciplinary civil engineering research into infrastructure and cities. Two workshops were held in 2019 to pressure-test the principles, after which the principles were refined. The workshops were attended by practicing civil engineers, urban designers, government think tanks, municipalities, and academics.

This section has introduced the problem space being addressed. Section 2 explores how engineering approaches to infrastructure and cities have evolved. Section 3 surfaces tensions around the intrinsic positive value of transdisciplinarity. Section 4 introduces the outcomes of this study - four principles for encouraging transdisciplinarity in engineering. Finally, Section 5 discusses the implications for UKCRIC.

\section{Engineering approaches to infrastructure and cities}

'In the early 21 st Century, it is clear that a radical shift in metaphor is taking place to thinking of cities and societies as organisms, as biological rather than physical systems.... This is also a switch from thinking of cities as being artefacts to be designed to thinking of them as systems that evolve, that grow and change in ways that might be steered and managed but rarely designed from the top down. This also reveals a shift from an emphasis on structure and form to one of behaviour and process and it mirrors the slow march from the physicalism which dominated city planning a generation or more ago to a serious concern for social process' (Batty, 2010: p. 100).

Complementing this is a growing realisation that engineering infrastructures, and in particular urban infrastructures, need to be conducted in ways that question perceptions of them as neutral or passive underlying material structures. 'Infrastructure is not identical to system or structure, as we currently see them, because infrastructure is defined by the movement or patterning of social form. It is the living mediation of what organizes life: the lifeworld of structure. Roads, bridges, schools, food chains, finance systems, prisons, families, districts, norms all the systems that link ongoing proximity to being in a world-sustaining relation' (Berlant, 2016: p. 393).

Berlant (2016: p. 394) also reflects on the relationship between infrastructure and politics: 'Given newly intensified tensions, anxieties, and antipathies at all levels of intimate abstraction, the question of politics becomes identical with the reinvention of infrastructures for managing the unevenness, ambivalence, violence, and ordinary contingency of contemporary existence'.

McCormack (2014) observed how physical infrastructures can be more than material objects and how their value (positive and negative) develops through their design, construction and use in, sometimes, unpredictable and emergent ways. He provides as one example accounts of the construction of the Brooklyn Bridge (Figure 1), which, once completed, provided physical connectivity, social mobility and social identity. It inspires poetry, prose, photography, paintings and movies; as well as providing a location for public demonstrations and events. He describes how, during its construction, there was political controversy when the contract for producing the steel cables was won by a local organisation that then supplied under-strength wire (luckily, the bridge had been over-engineered and it did not matter). Despite being so well engineered, the crucial role of Emily Roebling was purposefully diminished in order not to undermine faith in the construction of the bridge (because she was a woman).

In broadening the purview of civil engineers, there is a recognised tension with regard to rigour and scale. 'Engineers are not comfortable - and rightly so - with the idea of a profession which eschews rigour' (Jowitt, 2004: p. 79). Care must be taken not to conflate rigour and precision (an accusation that can reasonably be levelled at the swamp allegory by Schön (1987)). Wicked problems are often so complicated (displaying emergent properties and encompassing multiple technical and non-technical disciplines) that precision in addressing them is close to impossible. It does not follow, however, that the ways of addressing them lack rigour. This argument is particularly pertinent when dealing with complex systems thinking and digital technologies, whose relevance to infrastructure and cities is widely discussed but which are, themselves, emerging approaches (see Batty, 2012; Faithfull-Wright, 2018; Kitchin, 2014; Rathore et al., 2016; Samet, 2013). With regard to scale, 'A worldwide survey of engineering students ... confirms that they have difficulty making links between general sustainability theory and the detail of engineering practice' (Keirstead, 2014: p. 138), a difficulty that it would not be hard to imagine extends to other wicked problems.

\section{The intrinsic positive value of transdisciplinarity}

There is an assumption within transdisciplinarity that 'if transdisciplinary research is done under the "right" conditions and

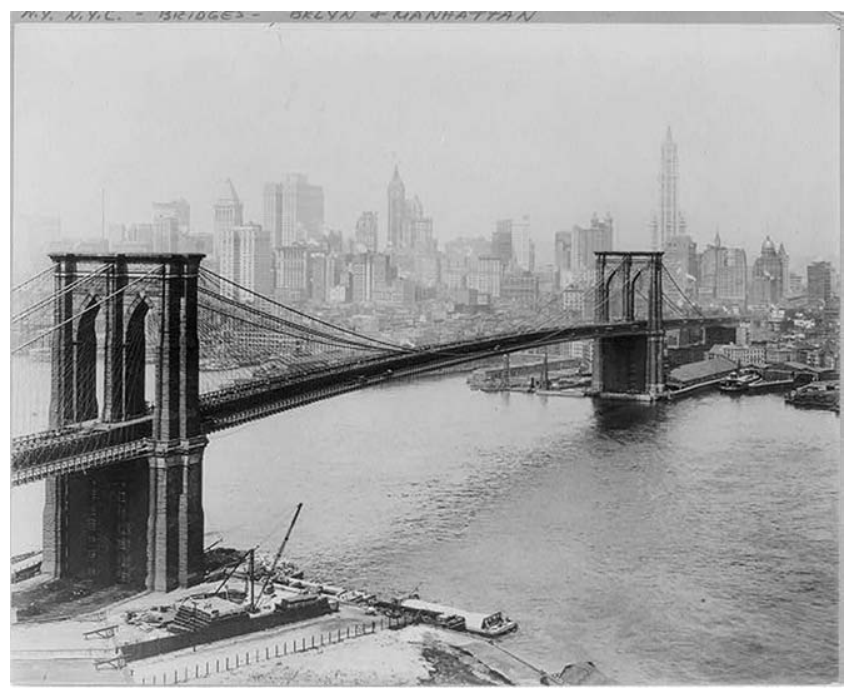

Figure 1. Brooklyn Bridge c. 1915 
with the "correct" procedures for engaging different types of stakeholders, it will generate relevant knowledge', yet this is far from a fait accompli (Klenk and Meehan, 2017: p. 28). Synthesis, a cornerstone of transdisciplinary research, is assumed to be both possible and desirable (Donaldson et al., 2010). However, too great a focus on the 'integration imperative' can, in fact, reduce the implementation of experimental methods and transformative ways of understanding (Klenk and Meehan, 2015). Although integration and synthesis can lead to new forms of knowledge, it is not guaranteed and it is possible for transdisciplinarity to lead to convergence and closure (Barry et al., 2008: p. 28).

It may be that certain areas of investigation are particularly conducive to transdisciplinarity. In fact, challenges that require the engagement of multiple disciplines have spurred, and continue to spur, the evolution of disciplines (Barry et al., 2008). Transdisciplinary approaches are rarely applied to simple problems because they are, simply, not necessary - the answers to simple problems often lie within the knowledge and expertise of a single discipline. The challenges posed by infrastructure and cities are neither simple nor singular. Such challenges appear messy 'because they are multiply determined and partially connected' (Donaldson et al., 2010: p. 1534).

Jessop and Sum (2001) describe the origin of scientific disciplines as pre-disciplinary, when academics were polymaths (or deep generalists (Tank, 2018)), and the future of scientific disciplines as post-disciplinary, when academics become polymaths once again. However, there is a crucial difference between the past and the future that they describe: the polymaths of the future exist within a scientific world of vastly expanded knowledge and an improved understanding of how individuals best work and work together. The days of the true polymath are in the past. Its counterpart, the transdisciplinarian, needs to be familiar with many disciplines, as well as with ways of bringing them productively together and innovatively interpreting the outcomes.

\section{Principles for encouraging transdisciplinarity in engineering}

Despite lacking certainty of positive outcomes, it seems that transdisciplinarity has something to offer in engineering. The question remains as to how to embed transdisciplinarity into engineering research and practice. In response, this briefing introduces a set of four 'principles of transdisciplinarity' that have been compiled from the literature reviews and refined through the workshops. The principles are positioned as the first step in fostering transdisciplinary approaches to the opportunities and challenges posed by infrastructure and cites. They underpin the enabling, facilitating and embedding of transdisciplinary thinking and practices into engineering. The applicability and importance of each principle depends on the context to which it is being applied (e.g. an organisation, a research project, an individual). Each principle opens the door to abundant complementary literatures and the opportunity to tailor transdisciplinarity to a given context. The four principles follow, with references found in Table 1:

- multidimensional problem framing - prioritising innovative and experimental problem framings and methodologies that ensure engagement across disciplines and domains and encourage systems thinking

- talented human resource - supporting an enabling mix of personal attributes and skill sets within individuals and teams; encouraging diversity of disciplines, domains, functions, disability, culture, race, religion, age, gender and sexual orientation

Table 1. Principles for encouraging transdisciplinarity in engineering

\begin{tabular}{|c|c|c|}
\hline \multicolumn{2}{|c|}{ Principle } & References \\
\hline 口 & $\begin{array}{l}\text { Multidimensional problem framing: prioritising innovative and } \\
\text { experimental problem framings and methodologies that ensure } \\
\text { engagement across disciplines and domains and encourage } \\
\text { systems thinking }\end{array}$ & $\begin{array}{l}\text { Bammer (2015, 2017), Barry et al. (2008), Brandt et al. (2013), Carew } \\
\text { and Wickson (2010), Harris et al. (2008), Jahn and Keil (2015), Lang } \\
\text { et al. (2012), Wickson et al. (2006) }\end{array}$ \\
\hline 口 & $\begin{array}{l}\text { Talented human resource: supporting an enabling mix of personal } \\
\text { attributes and skill sets within individuals and teams; encouraging } \\
\text { diversity of disciplines, domains, functions, disability, culture, race, } \\
\text { religion, age, gender and sexual orientation }\end{array}$ & $\begin{array}{l}\text { Bammer (2015), Boyko et al. (2015), Brandt et al. (2013), Graff (2015), } \\
\text { Harris et al. (2008), Klenk and Meehan (2015), Thompson et al. } \\
\text { (2017), Wickson et al. (2006) }\end{array}$ \\
\hline 口 & $\begin{array}{l}\text { Collaboration not competition: making collaboration the default } \\
\text { position no matter what the geographical scale, disciplinary scope, } \\
\text { domain span or societal impact of the issues being investigated } \\
\text { (and the response to them) }\end{array}$ & $\begin{array}{l}\text { Balsiger (2004), Bammer (2015), Barry et al. (2008), Bozhkova (2016), } \\
\text { Brandt et al., 2013), Carew and Wickson (2010), Donaldson et al. } \\
\text { (2010), Harris et al. (2008), Jahn and Keil (2015), Klenk and Meehan } \\
\text { (2015), Lang et al. (2012), Ledford (2015), Petts et al. (2008), } \\
\text { Ramadier (2004), Thompson et al. (2017), Wickson et al. (2006), } \\
\text { workshop held on } 10 \text { September, workshop held on } 20 \text { September }\end{array}$ \\
\hline$\square$ & $\begin{array}{l}\text { Supportive governance, structures and processes: ensuring that } \\
\text { governance, structures and processes are democratic, flexible, } \\
\text { integrative and motivational; that they promote continuity, } \\
\text { collaboration and interaction; that they reward interdisciplinarity } \\
\text { and support transdisciplinarity; that they are reflexive and } \\
\text { recursive; and that they do these things at the appropriate scales } \\
\text { and magnitudes for the issues under investigation }\end{array}$ & $\begin{array}{l}\text { Brandt et al. (2013), Carew and Wickson (2010), Harris et al. (2008), } \\
\text { Jahn and Keil (2015), Klenk and Meehan (2015), Lang et al. (2012), } \\
\text { Nowotny et al. (2001), Thompson et al. (2017) }\end{array}$ \\
\hline
\end{tabular}


- collaboration not competition - making collaboration the default position no matter what the geographical scale, disciplinary scope, domain span or societal impact of the issues being investigated (and the response to them)

- supportive governance, structures and processes - ensuring that governance, structures and processes are democratic, flexible, integrative and motivational; that they promote continuity, collaboration and interaction; that they reward interdisciplinarity and support transdisciplinarity; that they are reflexive and recursive; and that they do these things at the appropriate scales and magnitudes for the issues under investigation.

\section{Conclusions and recommendations}

This briefing explores two questions - (a) how are transdisciplinary approaches suited to the engineering of infrastructure and cities and (b) how is the engineering of infrastructure and cities suited to transdisciplinary approaches and finds that each has something to offer the other. The incentives are pressing, as digital technologies are already revolutionising how infrastructure and cities are designed, constructed, used and maintained. The outcomes of the study reveal clear areas for future investigation, as follows:

- disaggregating the organisational and programmatic elements for encouraging transdisciplinary research within engineering

- determining the locus of transdisciplinary values, knowledge, skills and attributes: the degree to which they must be embedded within an individual/team/organisation in order for transdisciplinary research to be successful

- developing ways to overcome perceived barriers to transdisciplinarity within engineering

- implementing the transdisciplinarity principles within UKCRIC.

UKCRIC is already making advances in each of these areas through Priming Laboratory Experiments on Infrastructure and Urban Systems (Plexus), one of its pump-priming projects, which is reflecting on its aspiration to move towards transdisciplinarity (see Leach, 2019). Beyond this, UKCRIC seeks to embed into all projects and programmes with which it is affiliated a culture of transdisciplinarity alongside delivering practical guidance and training. In order to achieve this, and if UKCRIC wishes to be seen as the national lead in transdisciplinary approaches to infrastructure and cities, then UKCRIC will need to establish and advance a programme of transdisciplinary research that includes an associated programme of education and training for all those who are drawn into the collaboratorium.

In truth, the verdict on the benefits of transdisciplinarity is still out. 'The celebrations have begun, but the actual data on what kind of difference this makes are not in' (Ledford, 2015: p. 311). Any assertion that transdisciplinary approaches have positive value must be underpinned by some standard of quality, but quality standards are not widely evident or agreed on - and this may very well be holding back the uptake of transdisciplinary methods (Jahn and Keil, 2015). Nonetheless, 'today ... we need people comfortable with collaborative work processes', people who 'accept the fallacy of the 'solution", because 'there are no creative solutions that don't end up creating other problems down the line' (Kahn and Diedrich, 2019: p. 13).

\section{Acknowledgements}

The authors are indebted to the UKCRIC community, particularly to Professors Brian Collins and Cynthia Mitchell for setting the engineering-transdisciplinarity agenda within UKCRIC. The authors gratefully acknowledge the financial support of the UK Engineering and Physical Sciences Research Council under grant numbers EP/R013535 (Plexus), EP/RO17727 (UKCRIC: Coordination Node) and EP/J017698 (Transforming the Engineering of Cities to Deliver Societal and Planetary Wellbeing). The characterisation of transdisciplinarity was tested with representatives from engineering, urban design, government think tanks, municipalities and academia at two workshops at $(a)$ the International Transdisciplinarity Conference 2019 (10 September 2019) and (b) the International Symposium for Next Generation Infrastructure 2019 (20 September 2019). Ethical approval for these activities was received from the University of Birmingham under reference number ERN_19-1201. The authors are grateful to the workshop participants for donating their time and expertise.

\section{REFERENCES}

Balsiger PW (2004) Supradisciplinary research practices: history, objectives and rationale. Futures 36(4): 407-422, https://doi.org/10. 1016/j.futures.2003.10.002.

Bammer G (2015) Interdisciplinarity: less vague please. Nature 526(7574): 506, https://doi.org/10.1038/526506c.

Bammer G (2017) Should we discipline interdisciplinarity? Palgrave Communications 3(30): 1-4, https://doi.org/10.1057/s41599-0170039-7.

Barry A, Born G and Weszkalnys G (2008) Logics of interdisciplinarity. Economy and Science 37(1): 20-49, https://doi.org/10.1080/ 03085140701760841.

Batty M (2010) Complexity in city systems: understanding, evolution, and design. In A Planner's Encounter with Complexity (de Roo G and Silva EA (eds)). Routledge, London, UK, pp. 99-122.

Batty M (2012) Building a science of cities. Cities 29(1): S9-S16, https:// doi.org/10.1016/j.cities.2011.11.008.

Berlant L (2016) The commons: infrastructures for troubling times. Environment and Planning D: Society and Space 34(3): 393-419, https://doi.org/10.1177/0263775816645989.

Boyko CT, MacKenzie AR and Leung H (2015) In spite of our own best interests: lessons from an interdisciplinary project on urban sustainability. Journal of Geography in Higher Education 39(2): 206-219, https://doi.org/10.1080/03098265.2014.956296.

Bozhkova E (2016) Interdisciplinary proposals struggle to get funded. Nature News, 29 June. See https://www.nature.com/news/ interdisciplinary-proposals-struggle-to-get-funded-1.20189 (accessed 10/08/2018)

Brandt P, Ernst A, Gralla F et al. (2013) A review of transdisciplinary research in sustainability science. Ecological Economics 92: 1-15, https://doi.org/10.1016/j.ecolecon.2013.04.008.

Carew AL and Wickson F (2010) The TD wheel: a heuristic to shape, support and evaluate transdisciplinary research. Futures 42(10): 1146-1155, https://doi.org/10.1016/j.futures.2010.04.025. 
Cavada M, Hunt DVL and Rogers CDF (2017) The role of infrastructure in smart cities. In ISNGI Conference Proceedings 2017. ISNGI, London, UK, pp. 80-88.

Donaldson A, Ward N and Bradley S (2010) Mess among disciplines: interdisciplinarity in environmental research. Environment and Planning A: Economy and Space 42(7): 1521-1536, https://doi.org/10. 1068/a42483.

Faithfull-Wright K (2018) Briefing: Smart cities: dividing the UK. Proceedings of the Institution of Civil Engineers - Smart Infrastructure and Construction 171(3): 88-92, https://doi.org/10. 1680/jsmic. 19.00002 .

Graff HJ (2015) Undisciplining Knowledge: Interdisciplinarity in the Twentieth Century. Johns Hopkins University Press, Baltimore, MD, USA.

Harris F, Lyon F and Clarke S (2008) Doing interdisciplinarity: motivation and collaboration in research for sustainable agriculture in the UK Area 41(4): 374-384, https://doi.org/10.1111/j.1475-4762.2008. 00859.x.

Head BW and Xiang WN (2016) Why is an APT approach to wicked problems important? Landscape and Urban Planning 154: 4-7, https://doi.org/10.1016/J.LANDURBPLAN.2016.03.018.

Jahn $T$ and Keil F (2015) An actor-specific guideline for quality assurance in transdisciplinary research. Futures 65: 195-208, https://doi.org/10. 1016/j.futures.2014.10.015.

Jahn T, Bergmann M and Keil F (2012) Transdisciplinarity: between mainstreaming and marginalization. Ecological Economics 79: 1-10, https://doi.org/10.1016/j.ecolecon.2012.04.017.

Jessop B and Sum NL (2001) Pre-disciplinary and post-disciplinary perspectives. New Political Economy 6(1): 89-101, https://doi.org/10. 1080/13563460020027777.

Jowitt PW (2004) Sustainability and the formation of the civil engineer. Proceedings of the Institution of Civil Engineers - Engineering Sustainability 157(2): 79-88, https://doi.org/10.1680/ensu.2004.157. 2.79 .

Kahn A and Diedrich L (2019) Cross the line to make the most of uncertainty. Scape 16: 12-17.

Keirstead J (2014) Introducing sustainable development with a mathematical model. Proceedings of the Institution of Civil Engineers - Engineering Sustainability 167(4): 137-142.

Kitchin R (2014) The real-time city? Big data and smart urbanism. GeoJournal 79(1): 1-14, https://doi.org/10.1007/s10708-013-9516-8.

Klenk N and Meehan K (2015) Climate change and transdisciplinary science: problematizing the integration imperative. Environmental Science and Policy 54: 160-167, https://doi.org/10.1016/j.envsci.2015. 05.017 .

Klenk NL and Meehan K (2017) Transdisciplinary sustainability research beyond engagement models: toward adventures in relevance. Environmental Science and Policy 78: 27-35, https://doi.org/10.1016/j. envsci.2017.09.006.

Lang DJ, Wiek A, Bergmann M et al. (2012) Transdisciplinary research in sustainability science: practice, principles, and challenges. Sustainability Science 7(1): 25-43, https://doi.org/10.1007/s11625011-0149-x.

Leach JM (2019s) Introducing PLEXUS, UKCRIC's Lab Pump Priming Project. UK Collaboratorium for Research on Infrastructure and Cities, London, UK. See http://www.ukcric.com/news/introducing-plexusukcric-s-lab-pump-priming-project (accessed 17/07/2020).

Ledford H (2015) How to solve the world's biggest problems. Nature 525(7569): 308-311, https://doi.org/10.1038/525308a.

McCormack DP (2014) Pipes and cables. In The Routledge Handbook of Mobilities (Adey P, Bissell D, Hannam K, Merriman P and Sheller M (eds)). Routledge, London, UK, pp. 225-232.

Nowotny H, Scott P and Gibbons M (2001) Re-thinking Science. Knowledge and the Public in an Age of Uncertainty. Polity, Cambridge, UK
Petts J, Owens S and Bulkeley H (2008) Crossing boundaries: interdisciplinarity in the context of urban environments. Geoforum 39(2): 593-601, https://doi.org/10.1016/j.geoforum.2006.02.008.

Ramadier T (2004) Transdisciplinarity and its challenges: the case of urban studies. Futures 36(4): 423-439, https://doi.org/10.1016/j. futures.2003.10.009.

Rathore MM, Ahmad A, Paul A and Rho S (2016) Urban planning and building smart cities based on the Internet of Things using Big Data analytics. Computer Networks 101: 63-80, https://doi.org/10.1016/j. comnet.2015.12.023.

Rittel HWJ and Webber MM (1973) Dilemmas in a general theory of planning. Policy Sciences 4(2): 155-169, https://doi.org/10.1007/ BF01405730

Samet RH (2013) Complexity, the science of cities and long-range futures Futures 47: 49-58, https://doi.org/10.1016/j.futures.2013.01.006.

Schön DA (1987) Education the Reflextive Practitioner: Toward a New Design of Teaching and Learning in the Professions. Jossey-Bass Publishers, San Francisco, CA, USA.

Tank A (2018) Why the world needs deep generalists, not specialists. The Startup - Medium, 7 November. See https://medium.com/swlh/whythe-world-needs-deep-generalists-not-specialists-b7c32e223c70 (accessed 22/03/2019).

Thompson MA, Owen S, Lindsay JM, Leonard GS and Cronin SJ (2017) Scientist and stakeholder perspectives of transdisciplinary research: early attitudes, expectations, and tensions. Environmental Science and Policy 74: 30-39, https://doi.org/10.1016/j.envsci.2017.04.006.

UKCRIC (UK Collaboratorium for Research on Infrastructure and Cities) (2020a) UK Collaboratorium for Research on Infrastructure and Cities. UKCRIC, London, UK. See https://www.ukcric.com (accessed 16/07/2020).

UKCRIC (2020b) Missions. UKCRIC, London, UK. See https://www. ukcric.com/about-ukcric/missions (accessed 16/07/2020).

UKCRIC Coordination Node (2019) Evidence Base and Portfolio of Tools and Techniques Underpinning UKCRIC's Research Capability in Cities. UKCRIC, London, UK.

Wickson F, Carew AL and Russell AW (2006) Transdisciplinary research: characteristics, quandaries and quality. Futures 38(9): 1046-1059, https://doi.org/10.1016/j.futures.2006.02.011.

\section{How can you contribute?}

To discuss this paper, please email up to 500 words to the editor at journals@ice.org.uk. Your contribution will be forwarded to the author(s) for a reply and, if considered appropriate by the editorial board, it will be published as discussion in a future issue of the journal.

Proceedings journals rely entirely on contributions from the civil engineering profession (and allied disciplines). Information about how to submit your paper online is available at www.icevirtuallibrary.com/page/authors, where you will also find detailed author guidelines. 